\title{
Effect of $\mathrm{CaCl}_{2}$ and $\mathrm{NaHCO}_{3}$ in Physiological Saline Solution on the Corrosion Behavior of an As-Extruded Mg-Zn-Y-Nd alloy
}

\author{
Baojie Wang ${ }^{1,3} \cdot$ Daokui Xu ${ }^{2} \cdot$ Tianyu Zhao ${ }^{1} \cdot$ Liyuan Sheng ${ }^{3}$
}

Received: 19 May 2020 / Revised: 3 June 2020 / Accepted: 6 June 2020 / Published online: 14 August 2020

(c) The Chinese Society for Metals (CSM) and Springer-Verlag GmbH Germany, part of Springer Nature 2020

\begin{abstract}
In this study, the corrosion behaviors of an as-extruded $\mathrm{Mg}-4 \% \mathrm{Zn}-2 \% \mathrm{Y}-1.8 \% \mathrm{Nd}$ (in wt.\%) alloy in different physiological saline solutions were investigated and compared. The results indicated that the alloy in the $9 \mathrm{~g} / \mathrm{L} \mathrm{NaCl}$ had the higher corrosion resistance than that containing with $\mathrm{CaCl}_{2}$ and $\mathrm{NaHCO}_{3}$. Moreover, it demonstrated that the corrosion behaviors of the alloy in two types of solutions were all dependent on the pre-immersion time. In the $9 \mathrm{~g} / \mathrm{L} \mathrm{NaCl}$ solution, the corrosion current densities of the alloy decreased firstly with the pre-immersion time being $<4 \mathrm{~h}$ and then increased with the pre-immersion time prolonging from 4 to $48 \mathrm{~h}$. However, in the $9 \mathrm{~g} / \mathrm{L} \mathrm{NaCl}$ solution containing with $\mathrm{CaCl}_{2}$ and $\mathrm{NaHCO}_{3}$, the corrosion current density of the alloy exhibited the adverse trend with the prolonging the pre-immersion time. Failure analysis demonstrated that the changes of corrosion resistance in two solutions were mainly dominated by the constituents formed in surface films.
\end{abstract}

Keywords Magnesium alloy $\cdot$ Biomaterial $\cdot$ Corrosion $\cdot$ Simulated body fluids $\cdot$ Pre-immersion

\section{Introduction}

Since $\mathrm{Mg}$ (magnesium) being as the essential element can take part in many metabolism reactions $[1,2]$ and the daily intake of $\mathrm{Mg}$ is about 300-400 $\mathrm{mg}$ for a normal adult [3], the degraded products from $\mathrm{Mg}$ implants are harmless to the human body [1-3], and the secondary surgery for removing the implanted $\mathrm{Mg}$ components can be avoided after the required functions being successfully recovered [2, 4]. Moreover, the density, elastic modulus and compressive yield strength of $\mathrm{Mg}$ alloys are all close to those of human bones [3]. Due to these comparable physical properties, the

Available online at http://link.springer.com/journal/40195.

Daokui Xu

dkxu@imr.ac.cn

1 School of Environmental and Chemical Engineering, Shenyang Ligong University, Shenyang 110159, China

2 CAS Key Laboratory of Nuclear Materials and Safety Assessment, Institute of Metal Research, Chinese Academy of Sciences, 62 Wencui Road, Shenyang 110016, China

3 Shenzhen Institute, Shenzhen Key Lab Human Tissue Regenerate and Repair, Peking University, Shenzhen 518057, China stress shielding issues of Mg implants can be well solved [5, 6]. Thus, the excellent biocompatibility of $\mathrm{Mg}$ alloys could ensure their promising future being as the desirable biomaterials [7-19]. However, the corrosion resistance of $\mathrm{Mg}$ alloys is quite poor and their corrosion rates are uncontrollable, which greatly limits their biomedical applications [20-23]. Moreover, the formed gas pockets due to the evolved hydrogen from the cathodic reactions can induce the separation of body tissue from $\mathrm{Mg}$ implants and finally cause the necrosis $[4,24]$. Thus, in order to obtain a good balance of properties in terms of corrosion resistance and considerate mechanical strength, different series of $\mathrm{Mg}$ alloys with good biocompatibility have been developed [25-29].

Since element $\mathrm{Nd}$ has a similar standard potential of $\mathrm{Mg}$, the $\mathrm{Mg}-\mathrm{Zn}-\mathrm{Y}-\mathrm{Nd}$ series alloys have much higher corrosion resistance and are more suitable for the medical applications when compared with other $\mathrm{Mg}$ alloys [30-32]. In the research of the degradation process of $\mathrm{Mg}-\mathrm{Zn}-\mathrm{Y}-\mathrm{Nd}$ alloys being as the coronary stent in simulated body fluids, Jin et al. reported that the corrosion attack of these alloys was uniform and their corrosion rates were closely related to the blood flow velocity and the concentration of chloride ions [33]. Moreover, Lu et al. reported that through controlling the contents of $\mathrm{Y}$ and $\mathrm{Nd}$, the uniformly distributed phases could simultaneously 
ensure the $\mathrm{Mg}-\mathrm{Zn}-\mathrm{Y}-\mathrm{Nd}$ alloy and have the high mechanical strength and good corrosion resistance in the simulated human body fluids [34].

Usually, the human body environment is quite complex and certain compositional differences in body fluids could exist between different aged adults. It has been reported that the levels of immunoglobulin, cholesterol and blood sugar increase with age, and the uric acid of male is much higher than that of female [35]. Therefore, in order to meet the requirements of biodegradation and metabolism in body fluids of different ages, it is necessary to investigate the effect of the changes in simulated body fluids on the corrosion behavior of $\mathrm{Mg}$ alloys. However, in previous work, a variety of simulated body fluids with differently proportioned ingredients such as the normal saline, Hank's, SPF (simulated physiological fluids) and PBS (phosphate buffer solution) solutions were chosen [36]. Among them, normal saline is a solution containing $0.9 \mathrm{wt} . \% \mathrm{NaCl}$ and its main function is to maintain the same osmotic pressure to the body. As for the PBS solution, its specific composition is $8.00 \mathrm{~g} / \mathrm{L} \mathrm{NaCl}, 0.20 \mathrm{~g} / \mathrm{L} \mathrm{KCl}, 2.89 \mathrm{~g} / \mathrm{L} \mathrm{Na}_{2} \mathrm{HPO}_{4} \cdot 12 \mathrm{H}_{2} \mathrm{O}$ and $0.20 \mathrm{~g} / \mathrm{L} \mathrm{KH}_{2} \mathrm{PO}_{4}$. The main function of PBS is to maintain osmotic pressure and to play buffering effect. As for the SBF solution, its specific composition is $8.00 \mathrm{~g} / \mathrm{L}$ $\mathrm{NaCl}, 0.40 \mathrm{~g} / \mathrm{L} \mathrm{KCl}, 0.12 \mathrm{~g} / \mathrm{L} \mathrm{Na}_{2} \mathrm{HPO}_{4} \cdot 12 \mathrm{H}_{2} \mathrm{O}, 0.06 \mathrm{~g} / \mathrm{L}$ $\mathrm{KH}_{2} \mathrm{PO}_{4}, 0.14 \mathrm{~g} / \mathrm{L} \mathrm{CaCl}_{2}, 0.35 \mathrm{~g} / \mathrm{L} \mathrm{NaHCO}_{3}$ and $0.20 \mathrm{~g} / \mathrm{L}$ $\mathrm{MgSO}_{4} \cdot 7 \mathrm{H}_{2} \mathrm{O}$. Compared with the SPF solution, Hank's solution has an extra ingredient of glucose, and its specific composition is $8.00 \mathrm{~g} / \mathrm{L} \mathrm{NaCl}, 0.40 \mathrm{~g} / \mathrm{L} \mathrm{KCl}, 0.14 \mathrm{~g} / \mathrm{L}$ $\mathrm{CaCl}_{2}, 0.35 \mathrm{~g} / \mathrm{L} \mathrm{NaHCO}{ }_{3}, 1.00 \mathrm{~g} / \mathrm{L} \mathrm{C}_{6} \mathrm{H}_{12} \mathrm{O}_{6}, 0.06 \mathrm{~g} / \mathrm{L}$ $\mathrm{MgSO}_{4} \cdot 7 \mathrm{H}_{2} \mathrm{O}, 0.06 \mathrm{~g} / \mathrm{L} \mathrm{KH}_{2} \mathrm{PO}_{4}, 0.06 \mathrm{~g} / \mathrm{L} \mathrm{Na}_{2} \mathrm{HPO}_{4} \cdot 12 \mathrm{H}_{2} \mathrm{O}$ and $0.1 \mathrm{~g} / \mathrm{L} \mathrm{MgCl}_{2} \cdot 6 \mathrm{H}_{2} \mathrm{O}$ [37]. Based on the description mentioned above, it indicates that obvious difference exists in the contained ingredients between these simulated body fluids, which makes it difficult to compare the corrosion data of $\mathrm{Mg}$ alloys measured in different fluids. Moreover, among these different ingredients, $\mathrm{NaHCO}_{3}$ can be hydrolyzed to form $\mathrm{H}^{+}$and $\mathrm{CO}_{3}{ }^{2-}$. Then, $\mathrm{CO}_{3}{ }^{2-}$ can react with $\mathrm{Ca}^{2+}$ to form $\mathrm{CaCO}_{3}$. Due to these reactions, the types and quantities of constituents formed in the product films can be influenced and subsequently result in the changes in corrosion resistance of the underneath $\mathrm{Mg}$ substrate. However, so far, researchers mainly focused on the corrosion behavior of $\mathrm{Mg}$ alloys in a specific simulated body fluid. As for the effect of changes in the simulated body fluid on the corrosion behavior of $\mathrm{Mg}$ alloys, no relevant work can be referred.

In this work, the main target is to investigate the corrosion behavior of an as-extruded $\mathrm{Mg}-4 \% \mathrm{Zn}-2 \% \mathrm{Y}-1.8 \% \mathrm{Nd}$ alloy in $9 \mathrm{~g} / \mathrm{L} \mathrm{NaCl}$ solutions containing with and without $\mathrm{CaCl}_{2}$ and $\mathrm{NaHCO}_{3}$. Moreover, the variations of electrochemical corrosion behavior of the alloy before and after pre-immersion in different solutions were compared and the underneath corrosion mechanisms were disclosed.

\section{Experimental}

The material selected for the current investigation was an as-extruded $\mathrm{Mg}-4 \% \mathrm{Zn}-2 \% \mathrm{Y}-1.8 \% \mathrm{Nd}$ (in wt.\%) alloy, which was prepared in an electric resistance furnace with the flowing mixed protective gas of $\mathrm{CO}_{2}$ and $\mathrm{SF}_{6}$ in a ratio of 100:1. After the pure $\mathrm{Mg}$ bulk being fully melted, pure $\mathrm{Zn}$ pieces, $\mathrm{Mg}-25 \mathrm{wt} . \% \mathrm{Y}$ and $\mathrm{Mg}-25 \mathrm{wt} . \% \mathrm{Nd}$ master alloys were added, respectively. Then, the molten liquid was stirred and subsequently kept for $30 \mathrm{~min}$ at $710^{\circ} \mathrm{C}$ for homogenization. Following this, the alloy was cast into a cylindrical ingot with a diameter of $200 \mathrm{~mm}$ and a height of $500 \mathrm{~mm}$. After being hold at $500{ }^{\circ} \mathrm{C}$ for $2 \mathrm{~h}$, the as-cast ingot was extruded into thick plate with a cross section of $10 \mathrm{~mm} \times 50 \mathrm{~mm}$ at $450{ }^{\circ} \mathrm{C}$. After extrusion, the plate was annealed at $300{ }^{\circ} \mathrm{C}$ for $30 \mathrm{~min}$ to relieve the residual stress. Then, the sliced rectangular samples from the plate were mechanically ground on $\mathrm{SiC}$ papers and subsequently polished up to their maximum roughness being less than $1 \mu \mathrm{m}$. To disclose the phase components in the alloy, phase analysis was carried out by using a D/Max $2400 \mathrm{X}$-ray diffractometer (XRD) with the monochromatic $\mathrm{Cu} \mathrm{K \alpha}$ radiation, a wavelength of $0.154056 \mathrm{~nm}$, a step size of $0.02^{\circ}$ and a scanning rate of $4 \% \mathrm{~min}$. By employing the scanning electron microscopy (SEM; XL30-FEG-ESEM) equipped with energy-dispersive X-ray spectroscopy (EDS), the microstructure of the polished cross section with the normal direction being parallel to the transverse direction (TD) of the plate was characterized. Hereafter, these samples were defined as the "TD" oriented samples.

For electrochemical tests, the "TD" oriented samples were selected and cold mounted with epoxy resin. The exposed area of sample surfaces is $1 \mathrm{~cm}^{2}$. Before the measurements, samples were, respectively, pre-immersed for $0.5 \mathrm{~h}, 2 \mathrm{~h}, 8 \mathrm{~h}, 24 \mathrm{~h}$ and $48 \mathrm{~h}$ in $9 \mathrm{~g} / \mathrm{L} \mathrm{NaCl}$ solutions containing with and without $0.14 \mathrm{~g} / \mathrm{L} \mathrm{CaCl}_{2}$ and $0.35 \mathrm{~g} / \mathrm{L}$ $\mathrm{NaHCO}_{3}$ at $37^{\circ} \mathrm{C}$. To ensure the stability of the temperature, a thermostat water bath was used. At a scan rate of $0.5 \mathrm{mV} \mathrm{s}^{-1}$, the potentiodynamic polarization curves were measured after being held for $600 \mathrm{~s}$ at open-circuit potential (OCP) in solutions using an EG\&G potentiostat model 273. During the measurements, a classical three electrode cell was employed with the Pt and saturated calomel being as the counter electrode and reference electrode, respectively. Then, the fittings of the obtained polarization curves were performed by employing the CorrView software in the traditional mode of Tafel. For each condition, three parallel samples were used for the electrochemical measurements to ensure their reproducibility.

To reflect the changes in corrosion severity with the prolongation of the immersion time, the hydrogen evolution and immersion experiments were carried out. The 
ratio between the volumes of solutions and samples was 300 . Moreover, to maintain a stable $\mathrm{pH}$ value of 7 , solutions were replaced every day. Based on the changes in measured volume of evolved hydrogen bubbles, the corrosion rates can be calculated [38].

By means of the stereo optical microscope (Keyence VHX 2000), the three-dimensional (3D) morphologies of the sample surfaces after being immersed, respectively, for $4 \mathrm{~h}$, $8 \mathrm{~h}$ and $48 \mathrm{~h}$ were observed to disclose and compare the evolution of corrosion severity in different solutions. The operational principle for taking 3D profiles with a high precision in height mainly includes two steps: (1) Automatically in situ focusing and taking photos layer by layer; (2) Automatically put these images together. Moreover, the polished cross sections of the differently immersed samples were characterized by using SEM, and the chemical compositions of surface films were identified by using EDS.

\section{Results}

\subsection{Microstructure}

The analyzed XRD phase pattern of the as-extruded $\mathrm{Mg}-4 \% \mathrm{Zn}-2 \% \mathrm{Y}-1.8 \% \mathrm{Nd}$ alloy is shown in Fig. 1. It demonstrates that the alloy is mainly composed of $\mathrm{W}$-phase and the $\alpha-\mathrm{Mg}$ matrix. In order to disclose the distribution and morphology of W-phase particles, the polished cross section with the normal direction being parallel to the TD direction of the plate was observed, as shown in Fig. 2. It reveals that the broken W-phase particles are distributed zonally and preferentially along the extrusion direction (Fig. 2a). High magnification image shows that the distribution of $\mathrm{W}$-phase particles is discontinuous and their sizes are generally $<5 \mu \mathrm{m}$ (Fig. 2b). Based on the EDS analyzed data, the main chemical elements of $\mathrm{W}$-phase are $\mathrm{Mg}, \mathrm{Zn}, \mathrm{Y}$ and

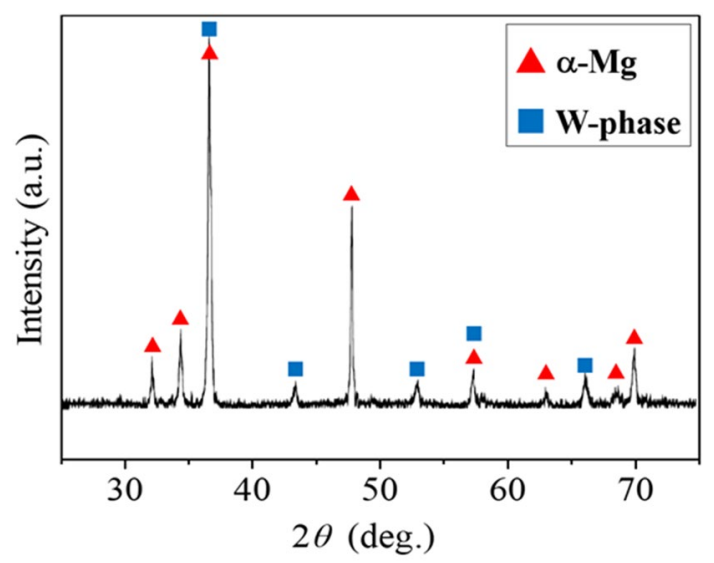

Fig. 1 XRD pattern of the as-extruded $\mathrm{Mg}-4 \% \mathrm{Zn}-2 \% \mathrm{Y}-1.8 \% \mathrm{Nd}$ alloy
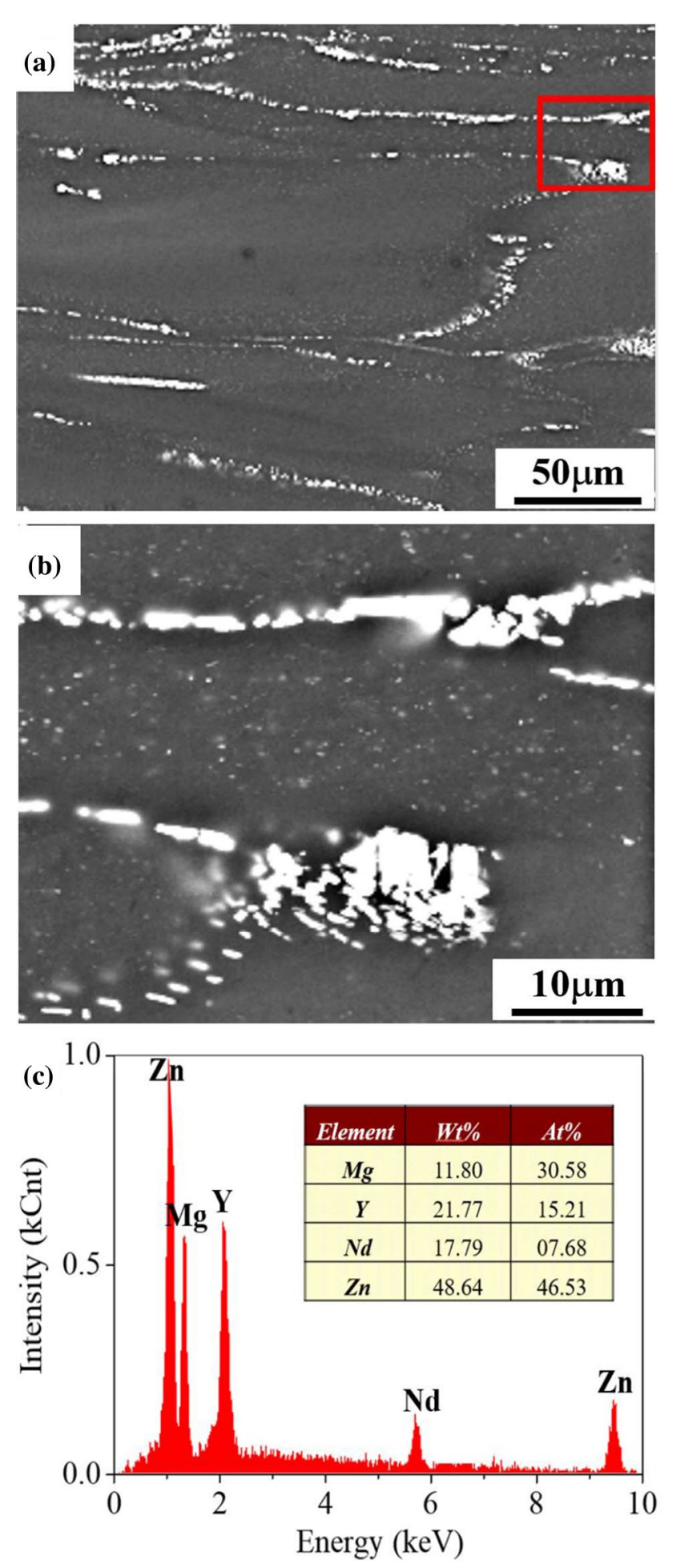

Fig. 2 SEM observations to the microstructure of the as-extruded $\mathrm{Mg}-4 \% \mathrm{Zn}-2 \% \mathrm{Y}-1.8 \% \mathrm{Nd}$ alloy: a low, b high magnification images. c EDS analysis to the bright particles in the image $\mathbf{b}$

$\mathrm{Nd}$ (Fig. 2c). Meanwhile, the atomic ratios of these four elements are close to those of $\mathrm{Mg}_{3} \mathrm{Zn}_{3}(\mathrm{Y}+\mathrm{Nd})_{2}$. In the previous work, Chen et al. reported that the addition of RE such as 
elements $\mathrm{Y}$ and $\mathrm{Nd}$ in $\mathrm{Mg}$-Zn-based alloys would preferentially combine with $\mathrm{Zn}$ to form the I-phase (quasicrystal
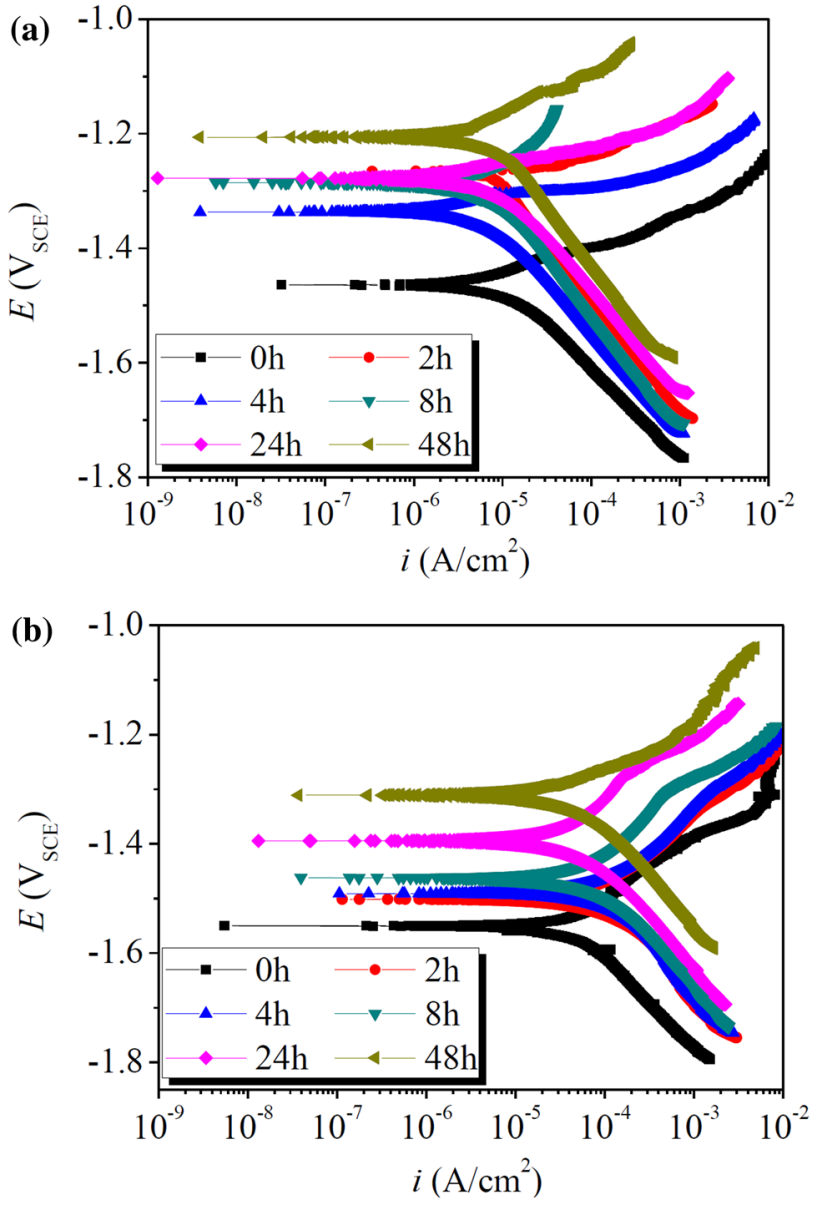

Fig. 3 Potentiodynamic polarization curves of the as-extruded $\mathrm{Mg}-$ $4 \% \mathrm{Zn}-2 \% \mathrm{Y}-1.8 \% \mathrm{Nd}$ alloy before and after pre-immersion for different times in solutions of: a $9 \mathrm{~g} / \mathrm{L} \mathrm{NaCl}$, b $9 \mathrm{~g} / \mathrm{L} \mathrm{NaCl}+0.14 \mathrm{~g} / \mathrm{L}$ $\mathrm{CaCl}_{2}+0.35 \mathrm{~g} / \mathrm{L} \mathrm{NaHCO}$ structure) and W-phase, while the formation of two types of secondary phases was closely dependent on the $\mathrm{Zn} / \mathrm{Y}$ and $\mathrm{Zn} / \mathrm{Nd}$ ratios [39]. Considering the solid solution of $\mathrm{Zn}$ in the matrix, the main secondary phase in $\mathrm{Mg}-\mathrm{Zn}-\mathrm{RE}$ alloys is $\mathrm{W}$-phase $\left(\mathrm{Mg}_{3} \mathrm{Zn}_{2} \mathrm{RE}_{2}\right)$ when the weight ratio of $\mathrm{Zn} / \mathrm{RE}$ is less than 1.1 [40-43]. In this work, the weight ratio of $\mathrm{Zn} /(\mathrm{Y}+\mathrm{Nd})$ in the as-extruded $\mathrm{Mg}-4 \% \mathrm{Zn}-2 \% \mathrm{Y}-1.8 \% \mathrm{Nd}$ alloy is 1.05 . Thus, in the currently investigated alloy, the $\mathrm{W}$-phase determined from the XRD analysis should be composed of $\mathrm{Mg}_{3} \mathrm{Zn}_{3} \mathrm{Y}_{2}$ and $\mathrm{Mg}_{3} \mathrm{Zn}_{3} \mathrm{Nd}_{2}$ phases.

\subsection{Electrochemically Evaluated Corrosion Response}

Figure 3 shows the potentiodynamic polarization curves of the as-extruded $\mathrm{Mg}-4 \% \mathrm{Zn}-2 \% \mathrm{Y}-1.8 \% \mathrm{Nd}$ alloy before and after pre-immersion in two different solutions for different times. Since the anodic and cathodic branches of all the polarization curves were not symmetrical, the corrosion parameters measured in two solutions were fitted from cathodic branches by Tafel extrapolation, as listed in Table 1. It reveals that in the $9 \mathrm{~g} / \mathrm{L} \mathrm{NaCl}$ solution, the corrosion current densities of the alloy decreased firstly with the pre-immersion time being less than $4 \mathrm{~h}$ and then increased with the pre-immersion time prolonging from $4 \mathrm{~h}$ to $48 \mathrm{~h}$. However, in the $9 \mathrm{~g} / \mathrm{L} \mathrm{NaCl}$ solution containing with $\mathrm{CaCl}_{2}$ and $\mathrm{NaHCO}_{3}$, the corrosion current density of the alloy exhibited the adverse trend with the increase in the pre-immersion time. Moreover, at the initial stage with no pre-immersion, the alloy has a low corrosion current density $\left(i_{\text {corr }}\right)$ of $8.30 \times 10^{-6} \mathrm{~A} / \mathrm{cm}^{2}$ in $9 \mathrm{~g} / \mathrm{L} \mathrm{NaCl}$ solution, whereas the $i_{\text {corr }}$ value is $30.39 \times 10^{-6} \mathrm{~A} / \mathrm{cm}^{2}$ when the $0.14 \mathrm{~g} / \mathrm{L} \mathrm{CaCl}_{2}$ and $0.35 \mathrm{~g} / \mathrm{L} \mathrm{NaHCO}_{3}$ was added in $9 \mathrm{~g} / \mathrm{L} \mathrm{NaCl}$ solution. However, after being pre-immersed for $48 \mathrm{~h}$, the difference in their $i_{\text {corr }}$ values measured in two solutions was significantly decreased.
Table 1 Fitting data from the polarization curves of the as-extruded $\mathrm{Mg}-4 \% \mathrm{Zn}-2 \% \mathrm{Y}$ $1.8 \% \mathrm{Nd}$ alloy in different solutions

\begin{tabular}{|c|c|c|c|}
\hline Solutions & $\begin{array}{l}\text { Pre-immersion time } \\
\text { (h) }\end{array}$ & $E_{\text {corr }}\left(\mathrm{V}_{\mathrm{SCE}}\right)$ & $i_{\text {corr }}\left(1 \times 10^{-6} \mathrm{~A} / \mathrm{cm}^{2}\right)$ \\
\hline \multirow[t]{6}{*}{$9 \mathrm{~g} / \mathrm{L} \mathrm{NaCl}$} & 0 & $-1.461 \pm 0.003$ & $8.30 \pm 0.15$ \\
\hline & 2 & $-1.266 \pm 0.002$ & $8.09 \pm 0.20$ \\
\hline & 4 & $-1.337 \pm 0.003$ & $4.13 \pm 0.05$ \\
\hline & 8 & $-1.285 \pm 0.004$ & $4.47 \pm 0.05$ \\
\hline & 24 & $-1.278 \pm 0.003$ & $5.62 \pm 0.05$ \\
\hline & 48 & $-1.206 \pm 0.002$ & $6.64 \pm 0.10$ \\
\hline \multirow{6}{*}{$\begin{array}{l}9 \mathrm{~g} / \mathrm{L} \mathrm{NaCl}+0.14 \mathrm{~g} / \mathrm{L} \\
\mathrm{CaCl}_{2}+0.35 \mathrm{~g} / \mathrm{L} \mathrm{NaHCO}\end{array}$} & 0 & $-1.589 \pm 0.005$ & $30.39 \pm 0.25$ \\
\hline & 2 & $-1.551 \pm 0.005$ & $58.90 \pm 1.80$ \\
\hline & 4 & $-1.525 \pm 0.004$ & $55.60 \pm 1.50$ \\
\hline & 8 & $-1.506 \pm 0.003$ & $55.01 \pm 1.30$ \\
\hline & 24 & $-1.412 \pm 0.002$ & $9.16 \pm 0.15$ \\
\hline & 48 & $-1.305 \pm 0.003$ & $5.29 \pm 0.10$ \\
\hline
\end{tabular}




\subsection{Hydrogen Evolution}

The volumes of evolved hydrogen versus immersion time curves of the as-extruded $\mathrm{Mg}-4 \% \mathrm{Zn}-2 \% \mathrm{Y}-1.8 \% \mathrm{Nd}$ alloy immersed in different solutions are shown in Fig. 4. It reveals that the hydrogen evolution rates of the alloy in different solutions are quite similar when the immersion time is $<10 \mathrm{~h}$. When the immersion time exceeds $10 \mathrm{~h}$, obvious difference in their hydrogen evolution rates can be observed. Based on the slopes of two curves, their hydrogen evolution rates can be determined. It exhibits that the hydrogen evolution rate in $9 \mathrm{~g} / \mathrm{L} \mathrm{NaCl}$ solution is much lower than that in the solution containing with $\mathrm{CaCl}_{2}$ and $\mathrm{NaHCO}_{3}$. Based on the slopes of curves, the hydrogen evolution rate in $9 \mathrm{~g} / \mathrm{L}$ $\mathrm{NaCl}$ solution is 0.28 times as high as that in the solution of $9 \mathrm{~g} / \mathrm{L} \mathrm{NaCl}+0.14 \mathrm{~g} / \mathrm{L} \mathrm{CaCl}{ }_{2}+0.35 \mathrm{~g} / \mathrm{L} \mathrm{NaHCO}_{3}$. Generally, the corrosion rates of $\mathrm{Mg}$ alloys due to the electrochemical reactions were proportional to the hydrogen evolution rates measured during the immersion at the OCP [44, 45]. Therefore, it demonstrates that the alloy has the higher corrosion resistance in the $9 \mathrm{~g} / \mathrm{L} \mathrm{NaCl}$ solution, which is basically in consistent with the results measured from the polarization curves (Fig. 3).

\subsection{Corrosion Morphology and Film Analysis}

To disclose the difference in corrosion severity of the asextruded $\mathrm{Mg}-4 \% \mathrm{Zn}-2 \% \mathrm{Y}-1.8 \% \mathrm{Nd}$ alloy occurred in two different solutions, their surface corrosion morphologies after immersion for $2 \mathrm{~h}, 8 \mathrm{~h}, 24 \mathrm{~h}$ and $48 \mathrm{~h}$ were compared, as shown in Fig. 5. It can be seen that at the early stage with immersion time of $2 \mathrm{~h}$ in two different solutions, obvious filiform corrosion occurs on the sample surfaces (Fig. 5a,e). Moreover, the residual un-attacked matrix in the solution of $9 \mathrm{~g} / \mathrm{L} \mathrm{NaCl}+0.14 \mathrm{~g} / \mathrm{L} \mathrm{CaCl}_{2}+0.35 \mathrm{~g} / \mathrm{L} \mathrm{NaHCO}_{3}$ is much less, indicating that its corrosion attack is much severer.

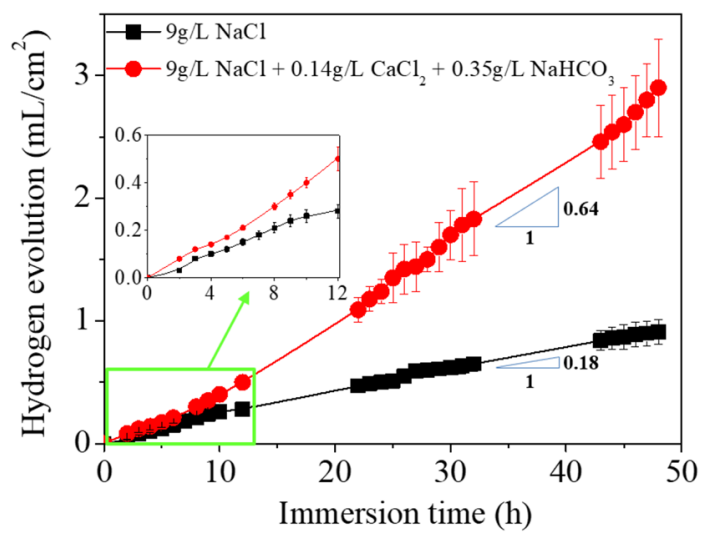

Fig. 4 Hydrogen evolution curves of the as-extruded $\mathrm{Mg}-$ $4 \% \mathrm{Zn}-2 \% \mathrm{Y}-1.8 \% \mathrm{Nd}$ alloy measured in different solutions
With the immersion time increasing, the filiform corrosion attack continues and aggravates for the samples being immersed in $9 \mathrm{~g} / \mathrm{L} \mathrm{NaCl}$ solution (Fig. 5b-d). Meanwhile, obviously, severe localized corrosion attack can be observed. However, for the samples being immersed in the solution of $9 \mathrm{~g} / \mathrm{L} \mathrm{NaCl}+0.14 \mathrm{~g} / \mathrm{L} \mathrm{CaCl}_{2}+0.35 \mathrm{~g} / \mathrm{L} \mathrm{NaHCO}_{3}$, no filiform corrosion can be observed, and the corrosion attack is quite homogenous and intensifies with prolonging the immersion time, resulting in the almost full coverage of the corrosion production films on the surfaces after $48 \mathrm{~h}$ immersion. To reveal the depth of the localized corroded areas, the three-dimensional (3D) profiles of the sample surfaces after being immersed in different solutions for $48 \mathrm{~h}$ were observed, as shown in Fig. 6. It can be seen that for the samples immersed in $9 \mathrm{~g} / \mathrm{L} \mathrm{NaCl}$ solution, the maximum depth of the localized corroded areas can reach $347 \mu \mathrm{m}$ (Fig. 6a), while the determined maximum depth in the solution of $9 \mathrm{~g} / \mathrm{L} \mathrm{NaCl}+0.14 \mathrm{~g} / \mathrm{L} \mathrm{CaCl}_{2}+0.35 \mathrm{~g} / \mathrm{L} \mathrm{NaHCO}_{3}$ is $46 \mu \mathrm{m}$ (Fig. 6b, c). Moreover, compared with the surfaces of samples being immersed in $9 \mathrm{~g} / \mathrm{L} \mathrm{NaCl}$ solution, the corrosion attack was widely occurred on the sample surfaces in the other solution. Figure 7 shows the cross-sectional morphologies of the as-extruded $\mathrm{Mg}-4 \% \mathrm{Zn}-2 \% \mathrm{Y}-1.8 \% \mathrm{Nd}$ alloy after being immersed for $48 \mathrm{~h}$ in two different solutions. It can be seen that the depths of the localized corroded areas in different solutions are basically the same, which is inconsistent with the 3D profiles. Since the formed surface film in the $9 \mathrm{~g} / \mathrm{L} \mathrm{NaCl}+0.14 \mathrm{~g} / \mathrm{L} \mathrm{CaCl}_{2}+0.35 \mathrm{~g} / \mathrm{L} \mathrm{NaHCO}_{3}$ solution is much thicker and covers the localized areas, the height difference in its 3D profile can just reflect the evenness of the surface film.

\section{Discussion}

Since the corrosion products can be formed on the surfaces after pre-immersion, their subsequent corrosion performance should be related to the characteristics and protectiveness of surface films. Generally, the Pilling-Bedworth ratios (PBR) of the formed surface films determines their protective capability to the substrate [46]. For the metallic materials, the coverage of surface film is insufficient and can hardly ensure the effective protection to the substrate when its PBR value is $<1$, whereas the formed film with the PBR value of $1-2$ is compact and has good protectiveness [46]. For $\mathrm{Mg}$ alloys immersed in $\mathrm{NaCl}$ solution, the formed surface film was mainly composed of $\mathrm{Mg}(\mathrm{OH})_{2}$ [45, 47, 48]. Although the PBR value of $\mathrm{Mg}(\mathrm{OH})_{2}$ is 1.77 , the $\mathrm{Cl}^{-}$in $\mathrm{NaCl}$ solution can easily induce the dissolution of $\mathrm{Mg}(\mathrm{OH})_{2}$ and subsequent transformation to $\mathrm{MgCl}_{2}$ [49]. Moreover, the $\mathrm{W}$-phases being as the cathode could accelerate the corrosion of their surrounding $\mathrm{Mg}$ matrix and then lead to the pitting formation [32]. Therefore, for the 

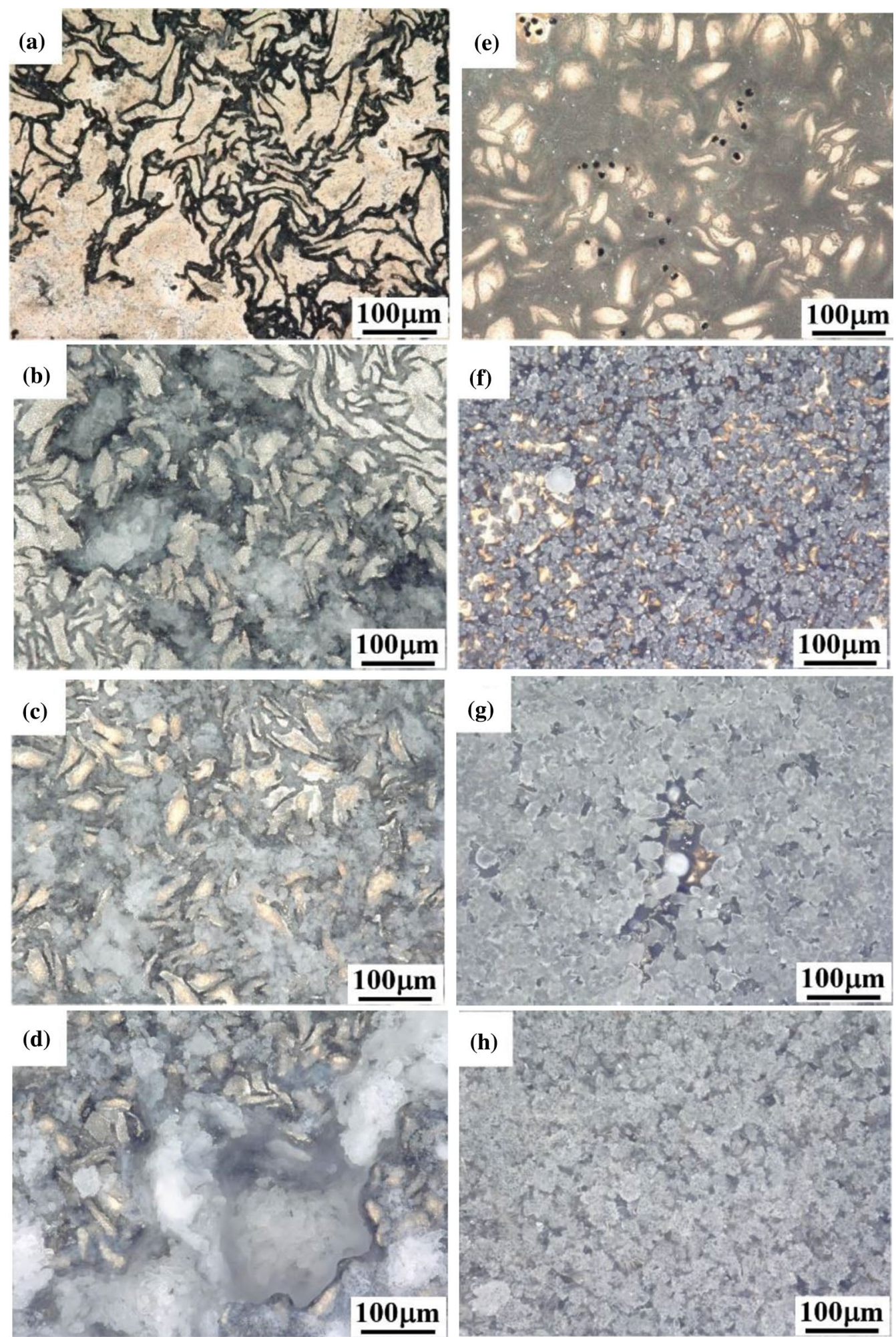

Fig. 5 Surface corrosion morphologies of the as-extruded $\mathrm{Mg}-4 \% \mathrm{Zn}-2 \% \mathrm{Y}-1.8 \% \mathrm{Nd}$ alloy after immersion for: a $2 \mathrm{~h}, \mathbf{b} 8 \mathrm{~h}$, c $24 \mathrm{~h}$, d $48 \mathrm{~h}$ in $9 \mathrm{~g} / \mathrm{L} \mathrm{NaCl}$ solution; e $2 \mathrm{~h}, \mathbf{f} 8 \mathrm{~h}, \mathbf{g} 24 \mathrm{~h}, \mathbf{h} 48 \mathrm{~h}$ in $9 \mathrm{~g} / \mathrm{L} \mathrm{NaCl}+0.14 \mathrm{~g} / \mathrm{L} \mathrm{CaCl}_{2}+0.35 \mathrm{~g} / \mathrm{L} \mathrm{NaHCO}_{3}$ solution 
(a)

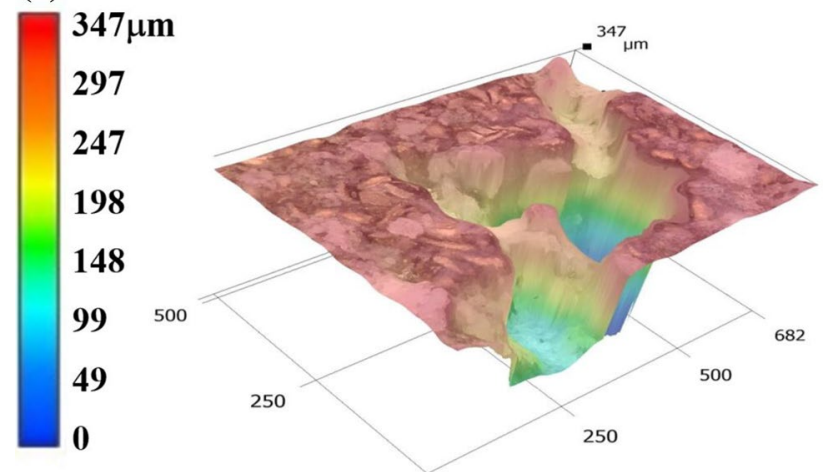

(b)

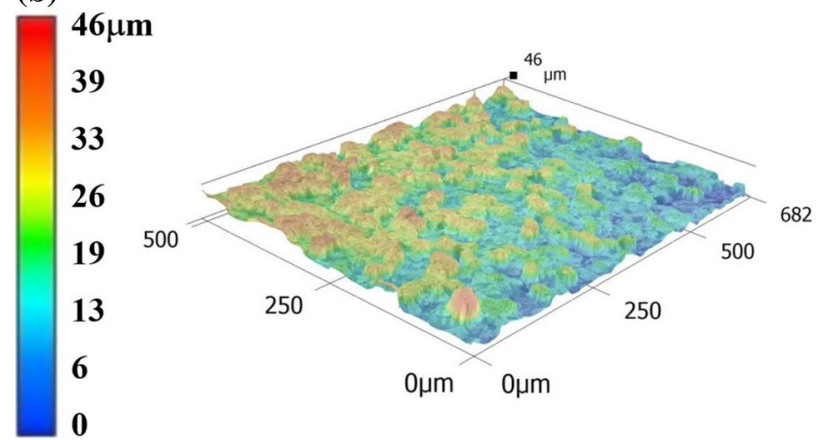

Fig. 6 Three-dimensional (3D) images of the as-extruded $\mathrm{Mg}-$ $4 \% \mathrm{Zn}-2 \% \mathrm{Y}-1.8 \% \mathrm{Nd}$ alloy after being immersed for $48 \mathrm{~h}$ in solutions of: a $9 \mathrm{~g} / \mathrm{L} \mathrm{NaCl}$ and $\mathbf{b} 9 \mathrm{~g} / \mathrm{L} \mathrm{NaCl}+0.14 \mathrm{~g} / \mathrm{L} \mathrm{CaCl}{ }_{2}+0.35 \mathrm{~g} / \mathrm{L}$ $\mathrm{NaHCO}_{3}$

samples in the $9 \mathrm{~g} / \mathrm{L} \mathrm{NaCl}$ solution, the formed $\mathrm{Mg}(\mathrm{OH})_{2}$ film cannot provide a complete protection to the matrix and severely localized corrosion attack occurs (Fig. 7a).

For the samples immersed in the $9 \mathrm{~g} / \mathrm{L} \mathrm{NaCl}$ solution containing with $\mathrm{CaCl}_{2}$ and $\mathrm{NaHCO}_{3}$, besides the formation of $\mathrm{Mg}(\mathrm{OH})_{2}$, the reactions between $\mathrm{CO}_{3}{ }^{2-}, \mathrm{Ca}^{2+}$ and the dissolved $\mathrm{Mg}^{2+}$ can also occur to form $\mathrm{CaCO}_{3}$ and $\mathrm{MgCO}_{3}$ in the surface films [50, 51]. The main reactions for their formation can be expressed as follows. Due to the hydrolytic reaction of $\mathrm{CaCl}_{2}$ and $\mathrm{NaHCO}_{3}$, the following ions are produced.

$\mathrm{CaCl}_{2} \rightarrow \mathrm{Ca}^{2+}+2 \mathrm{Cl}^{-}$,

$\mathrm{NaHCO}_{3} \rightarrow \mathrm{Na}^{+}+\mathrm{HCO}_{3}^{-}$,

$\mathrm{HCO}_{3}^{-} \rightarrow \mathrm{H}^{+}+\mathrm{CO}_{3}^{2-}$.

Then, the anodic reaction is:

$\mathrm{Mg} \rightarrow \mathrm{Mg}^{2+}+2 \mathrm{e}$.

Cathodic reactions are:
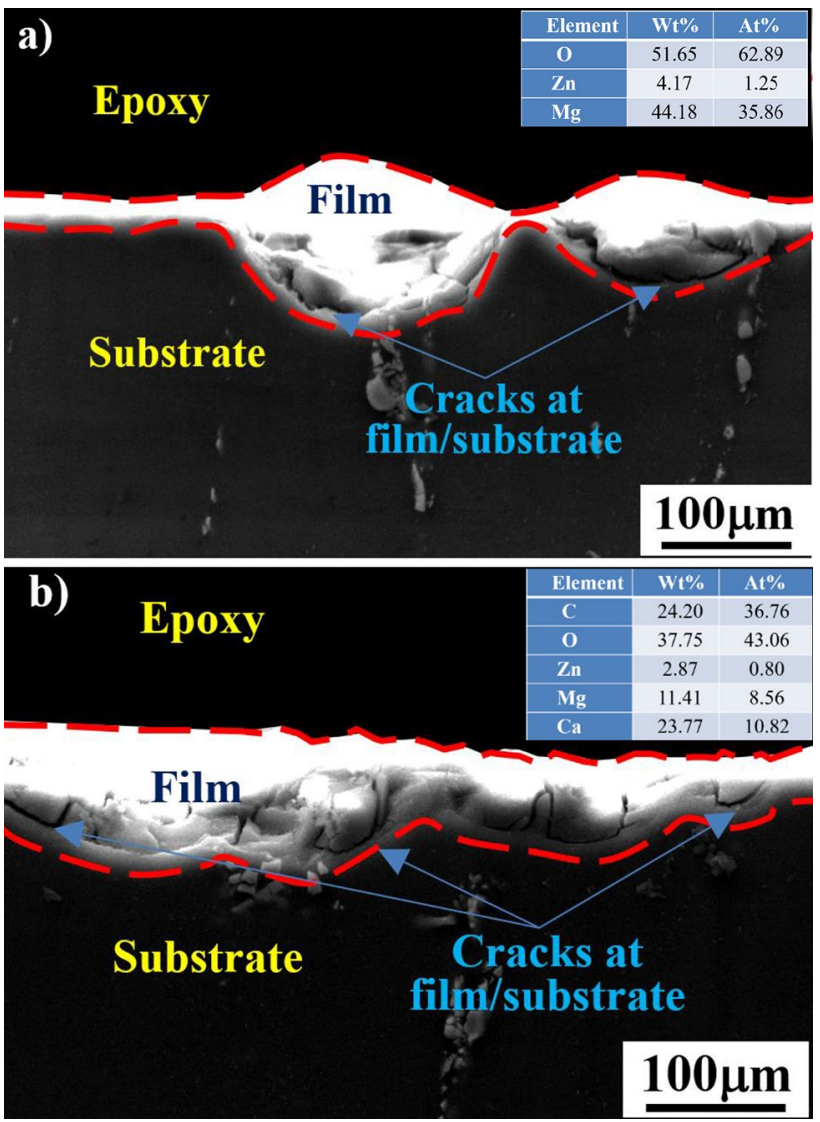

Fig. 7 SEM images of the cross sections of the as-extruded $\mathrm{Mg}-$ $4 \% \mathrm{Zn}-2 \% \mathrm{Y}-1.8 \% \mathrm{Nd}$ alloy after being immersed for $48 \mathrm{~h}$ in solutions of: a $9 \mathrm{~g} / \mathrm{L} \mathrm{NaCl}, \mathbf{b} 9 \mathrm{~g} / \mathrm{L} \mathrm{NaCl}+0.14 \mathrm{~g} / \mathrm{L} \mathrm{CaCl}_{2}+0.35 \mathrm{~g} / \mathrm{L} \mathrm{NaHCO}_{3}$

$2 \mathrm{H}^{+}+2 \mathrm{e} \rightarrow \mathrm{H}_{2} \uparrow$,

$2 \mathrm{H}_{2} \mathrm{O}+2 \mathrm{e} \rightarrow 2 \mathrm{OH}^{-1}+\mathrm{H}_{2} \uparrow$.

The overall reactions are:

$\mathrm{Mg}^{2+}+\mathrm{OH}^{-1}+\mathrm{CO}_{3}^{2-} \rightarrow \mathrm{Mg}(\mathrm{OH})_{2} \downarrow+\mathrm{MgCO}_{3} \downarrow$,

$\mathrm{Ca}^{2+}+\mathrm{CO}_{3}^{2-} \rightarrow \mathrm{CaCO}_{3} \downarrow$.

It has been reported that the standard enthalpies for the formation of $\mathrm{Mg}(\mathrm{OH})_{2}, \mathrm{CaCO}_{3}$ and $\mathrm{MgCO}_{3}$ were - 924.66, $-1206.9,-1096 \mathrm{~kJ} \mathrm{~mol}^{-1}$, respectively [46]. Since a substance with a low standard formation enthalpy has the good chemical stability, the formed $\mathrm{CaCO}_{3}$ and $\mathrm{MgCO}_{3}$ in the surface film are much stable than that of $\mathrm{Mg}(\mathrm{OH})_{2}$ during the immersion in $9 \mathrm{~g} / \mathrm{L} \mathrm{NaCl}$ solution containing with $\mathrm{CaCl}_{2}$ and $\mathrm{NaHCO}_{3}$. Moreover, the PBR values of $\mathrm{CaCO}_{3}$ and $\mathrm{MgCO}_{3}$ were calculated to be 1.43 and 2.04 [46]. Based on their PBR values, it can be predicted that the presence of $\mathrm{CaCO}_{3}$ and $\mathrm{MgCO}_{3}$ in surface films should be beneficial 
for improving the corrosion resistance of the alloy, which is contradictory to the experimental measurements. In the previous work, Zeng et al. reported that the PBR value can also reflect the stress state of the oxide film [46], i.e., a tensile stress develops in the film when PBR values are less than 1 and a compressive stress develops in the film when PBR values are larger than 1 . Moreover, the larger PBR values can cause the higher growth stress and subsequently induce the cracking of the surface films. Therefore, for the samples immersed in the $9 \mathrm{~g} / \mathrm{L} \mathrm{NaCl}$ solution containing with $\mathrm{CaCl}_{2}$ and $\mathrm{NaHCO}_{3}$, the formed $\mathrm{MgCO}_{3}$ and $\mathrm{CaCO}_{3}$ can quickly cover the surfaces at the early stage. Meanwhile, the pits due to the galvanic corrosion between the $\mathrm{W}$-phases and $\mathrm{Mg}$ matrix can be easily filled by the $\mathrm{MgCO}_{3}$ and $\mathrm{CaCO}_{3}$. With the immersion time increasing, the surface film thickens gradually, resulting in the increased internal stress and subsequently debonding at film/substrate and cracking in the interior of films (Fig. 7b). Thus, when $\mathrm{CaCl}_{2}$ and $\mathrm{NaHCO}_{3}$ are added in the $9 \mathrm{~g} / \mathrm{L} \mathrm{NaCl}$ solution, the corrosion resistance of the alloy will degrade and is mainly determined by the competition between film cracking and the formation new layers of $\mathrm{MgCO}_{3}$ and $\mathrm{CaCO}_{3}$ product films.

\section{Conclusions}

Through investigating and comparing the corrosion behavior of an as-extruded $\mathrm{Mg}-4 \% \mathrm{Zn}-2 \% \mathrm{Y}-1.8 \% \mathrm{Nd}$ alloy in two different simulated body fluids, several conclusions can be reached. The corrosion performance in $9 \mathrm{~g} / \mathrm{L} \mathrm{NaCl}$ solution is much better than those in $9 \mathrm{~g} / \mathrm{L} \mathrm{NaCl}$ solutions containing with $\mathrm{CaCl}_{2}$ and $\mathrm{NaHCO}_{3}$. In $9 \mathrm{~g} / \mathrm{L} \mathrm{NaCl}$ solutions, the corrosion attack is relatively weaker, but the localized corrosion is much severe. In the $9 \mathrm{~g} / \mathrm{L} \mathrm{NaCl}$ solutions containing with $\mathrm{CaCl}_{2}$ and $\mathrm{NaHCO}_{3}$, the corrosion attack is strong and homogeneous. The main reason is that the surface film thickens and cracks can occur at film/substrate interfaces and in the interior of film with the increase in the immersion time, resulting in its poor protectiveness to the substrate and the corrosion resistance of the alloy being mainly determined by the competition between film cracking and the formation new layers of $\mathrm{MgCO}_{3}$ and $\mathrm{CaCO}_{3}$ products.

Acknowledgements This work was supported by the National Key Research and Development Program of China under Grant (Nos. 2017YFB0702001 and 2016YFB0301105), the Liaoning Province's project of "Revitalizing Liaoning Talents" (XLYC1907062), the National Natural Science Foundation of China Projects under Grant (Nos. 51871211 and 51701129), the Doctor Startup Fund of Natural Science Foundation Program of Liaoning Province (No. 2019-BS200), the Strategic New Industry Development Special Foundation of Shenzhen (JCYJ20170306141749970), the funds of the International Joint Laboratory for Light Alloys, the Liaoning BaiQianWan Talents Program, the Domain Foundation of Equipment Advance Research of 13th Five-year Plan (61409220118), the Innovation Fund of Institute of Metal Research (IMR), Chinese Academy of Sciences (CAS), the National Basic Research Program of China (973 Program) project under Grant No. 2013CB632205.

\section{References}

[1] A. Hartwig, Mutat. Res. -Fundam. Mol. Mech. Mutagen. 475, 113 (2001)

[2] X.F. Cui, Y.Y. Yang, E.B. Liu, G. Jin, J.G. Zhong, Q.F. Li, Appl. Surf. Sci. 257, 9703 (2011)

[3] G.L. Song, Corros. Sci. 49, 1696 (2007)

[4] F. Witte, V. Kaese, H. Haferkamp, E. Switzer, A. Meyer-Lindenberg, C.J. Wirth, H. Windhagen, Biomaterials 26, 3557 (2005)

[5] C.E. Wen, M. Mabuchi, Y. Yamada, K. Shimojima, Y. Chino, T. Asahina, Scr. Mater. 45, 1147 (2001)

[6] J. Levesque, H. Hermawan, D. Dube, D. Mantovani, Acta Biomater. 4, 284 (2008)

[7] B.J. Wang, S.D. Wang, D.K. Xu, E.H. Han, J. Mater. Sci. Technol. 33, 1075 (2017)

[8] B.J. Wang, D.K. Xu, J.H. Dong, W. Ke, J. Mater. Sci. Technol. 32, 646 (2016)

[9] X.J. Wang, D.K. Xu, R.Z. Wu, X.B. Chen, Q.M. Peng, L. Jin, Y.C. Xin, Z.Q. Zhang, Y. Liu, X.H. Chen, G. Chen, K.K. Deng, H.Y. Wang, J. Mater. Sci. Technol. 34, 245 (2018)

[10] B.N. Du, Z.Y. Hu, J.L. Wang, L.Y. Sheng, H. Zhao, Y.F. Zheng, T.F. Xi, Bioact. Mater. 5, 219 (2020)

[11] P.F. Cheng, C.L. Zhao, P. Han, J.H. Ni, S.X. Zhang, X.N. Zhang, Y.M. Chai, J. Mater. Sci. Technol. 32, 883 (2016)

[12] F. Zhong, H.J. Wu, Y.L. Jiao, R.Z. Wu, J.H. Zhang, L.G. Hou, M.L. Zhang, J. Mater. Sci. Technol. 39, 124 (2020)

[13] S.Q. Yin, W.C. Duan, W.H. Liu, L. Wu, J.M. Yu, Z.L. Zhao, M. Liu, P. Wang, J.Z. Cui, Z.Q. Zhang, Corros. Sci. 166, 108419 (2020)

[14] M. Duan, L. Luo, Y. Liu, J. Alloys Compd. 823, 153691 (2020)

[15] B.J. Wang, D.K. Xu, S.D. Wang, L.Y. Sheng, R.C. Zeng, E.H. Han, Int. J. Fatigue 120, 46 (2019)

[16] C.Q. Li, D.K. Xu, B.J. Wang, L.Y. Sheng, R.Z. Wu, E.H. Han, J. Mater. Sci. Technol. 35, 2477 (2019)

[17] B.J. Wang, D.K. Xu, X. Cai, Y.X. Qiao, L.Y. Sheng, J. Mater. Sci. Technol. 53, 102 (2020)

[18] B.J. Wang, J.Y. Luan, D.K. Xu, J. Sun, C.Q. Li, E.H. Han, Acta Metall. Sin. -Engl. Lett. 32, 1 (2019)

[19] D.C. Xue, Y.H. Yun, Z.Q. Tan, Z.Y. Dong, M.J. Schulz, J. Mater. Sci. Technol. 28, 261 (2012)

[20] G. Han, J.Y. Lee, Y.C. Kim, J.H. Park, D.I. Kim, H.S. Han, S.J. Yang, H.K. Seok, Corros. Sci. 63, 316 (2012)

[21] Y. Cheng, Y.J. Fu, Y.C. Xin, G. Chen, P.D. Wu, X.X. Huang, Q. Liu, Int. J. Plast. 102754 (2020)

[22] G. Chen, Y.J. Fu, Y. Cui, J.W. Gao, X. Guo, H. Gao, S.Z. Wu, J. Lu, Q. Lin, S.W. Shi, Int. J. Fatigue 127, 461 (2019)

[23] G. Chen, J.N. Ren, H. Gao, Y. Cui, X. Chen, Int. J. Fatigue 103, 466 (2017)

[24] L. Li, J. Gao, Y. Wang, Surf. Coat. Technol. 185, 92 (2004)

[25] Y. Xin, T. Hu, P.K. Chu, Acta Biomater. 7, 1452 (2011)

[26] A.C. Hänzi, I. Gerber, M. Schinhammer, J.F. Löffler, P.J. Uggowitzer, Acta Biomater. 6, 1824 (2010)

[27] F. Witte, J. Fischer, J. Nellesen, H. Crostack, V. Kaese, A. Pisch, F. Beckmann, H. Windhagen, Biomaterials 27, 1013 (2006)

[28] A. Atrens, M. Liu, N.I. Zainal Abidin, Mater. Sci. Eng. B 176, $1609(2011)$

[29] F. Witte, N. Hort, C. Vogt, S. Cohen, K.U. Kainer, R. Willumeit, F. Feyerabend, Curr. Opin. Solid State Mater. Sci. 12, 63 (2008)

[30] X.B. Zhang, L. Mao, G.Y. Yuan, Z.Z. Wang, Rare Met. Mater. Eng. 42, 1300 (2013) 
[31] X.B. Zhang, G.Y. Yuan, Z.Z. Wang, Mater. Sci. Technol. 29, 111 (2013)

[32] Y.Y. Kang, B.N. Du, Y.M. Li, B.J. Wang, L.Y. Sheng, L.Q. Shao, Y.F. Zheng, T.F. Xi, J. Mater. Sci. Technol. 35, 6 (2019)

[33] S.T. Jin, Simulation for the degradation process of $\mathrm{Mg}-\mathrm{Zn}-\mathrm{Y}-\mathrm{Nd}$ alloy coronary stent. Master dissertation, Zhengzhou University, (2017)

[34] X.L. Lu, X.L. Yao, Y. Li, Chin. J. Tissue Eng. Res. 21, 1571 (2017)

[35] Y.N. Gu. Analysis on changes of the random population's humeral immunity and biochemical index with aging and forecast value of biological age. Master dissertation. Dalian Medical University (2007)

[36] Y. Wan, Y.N. Wang, Q. Wang, L.L. Tan, K. Yang, Y.D. Li, W.R. Li, Mater. Rev. 6, 66 (2011)

[37] J.J. Huang, G.D. Zhang, Y.B. Ren, B.C. Zhang, K. Yang, J. Funct. Mater. 5, 1880 (2007)

[38] Y.C. Xin, C.L. Liu, X.M. Zhang, G.Y. Tang, X.B. Tian, P.K. Chu, J. Mater. Res. 22, 2004 (2007)

[39] T.J. Chen, D.H. Zhang, W. Wang, Y. Ma, Y. Hao, China Foundry 12, $339(2015)$

[40] D.K. Xu, E.H. Han, Prog. Nat. Sci.: Mater. Int. 22, 364 (2012)
[41] D.K. Xu, W.T. Tang, L. Liu, Y.B. Xu, E.H. Han, J. Alloys Compd. 432, 129 (2007)

[42] D.K. Xu, L. Liu, Y.B. Xu, E.H. Han, J. Alloys Compd. 426, 155 (2006)

[43] D.K. Xu, W.T. Tang, L. Liu, Y.B. Xu, E.H. Han, J. Alloys Compd. 461, 248 (2008)

[44] G. Song, R. Mishra, Z. Xu, Electrochem. Commun. 12, 1009 (2010)

[45] S.D. Wang, D.K. Xu, B.J. Wang, L.Y. Sheng, Y.X. Qiao, E.H. Han, C. Dong, Corros. Sci. 142, 185 (2018)

[46] R.C. Zeng, L. Sun, Y.F. Zheng, H.Z. Cui, E.H. Han, Corros. Sci. 79, 69 (2014)

[47] B.J. Wang, D.K. Xu, J. Sun, E.H. Han, Corros. Sci. 157, 347 (2019)

[48] B.J. Wang, D.K. Xu, L.Y. Sheng, E.H. Han, J. Sun, J. Mater. Sci. Technol. 35, 2423 (2019)

[49] Z.J. Li, X.N. Gu, S.Q. Lou, Y.F. Zheng, Biomaterials 29, 1329 (2008)

[50] R.C. Zeng, Y. Hu, S.K. Guan, H.Z. Cui, E.H. Han, Corros. Sci. 86, 171 (2014)

[51] B.J. Wang, D.K. Xu, J.H. Dong, X.B. Chen, W. Ke, J. Mater. Sci. Technol. 34, 1756 (2018) 